DOI: https://doi.org/10.32839/2304-5809/2020-78.1-16

UDC (811.161.2:81)'373.21(477.43)

Ordynska Ilona

Bohdan Khmelnytskyi National Academy of the State Border Guard Service of Ukraine

\title{
HISTORY OF STUDYING PROPER NAMES OF SMALL GEOGRAPHICAL OBJECTS OF NORTHERN KHMELNYTSKYI REGION
}

Summary. The article describes the history of microtoponymic studying of Northern Khmelnytskyi region. Attention is drawn to the study of microtoponym-related proper geographical names and local geographical terms. The formation of the terminological system of microtoponymics has been clarified. The basic theoretical provisions concerning the elucidation of the nature of microtoponyms, the separation of their differential features, the structuring of the microtoponymic extend, are outlined in such monographs, dictionaries and collections of scientific works as: "Microtoponymy" (Moscow, 1967), "Basic System and Onomastics Terminology" (Skopje, 1983), "Dictionary of Russian Onomastic Terminology" by N.V. Podolskaya (Moscow, 1988), "Dictionary of Ukrainian Onomastic Terminology" by D.G. Buchko and N.V. Tkachova (Kharkov, 2012), Encyclopedia "Slavic Onomastics" (Krakow-Warsaw, 2002-2003), two monographs by M. Torchynsky "The Structure of the Onym Extend of the Ukrainian Language" (Khmelnitsky, 2008), "The Structure of the Onym Extend of the Ukrainian Language. Part 2. Functioning of the Proper Names" (Khmelnitsky, 2009), "Theory and Methodology of Onomastic Research" (Moscow, 1986), "Ukrainian Language: Encyclopedia” (Kyiv, 2004), "Ukrainian Onomastic Terminology: (Project)" V.V.Nimchuk (Kyiv, 1966), as well as in a number of theses.

Keywords: proper name of a small geographical object, microtoponym, microtoponymics, microtoponymist, microtoponymy.

Ординська І.Я. Національна академія Державної прикордонної служби України імені Богдана Хмельницького

\section{ІСТОРІЯ ВИВЧЕННЯ ВЛАСНИХ НАЗВ НЕВЕЛИКИХ ГЕОГРАФІЧНИХ ОБ’ЄКТІВ ПІВНІЧНОЇ ХМЕЛЬНИЧЧИНИ}

Анотація. Серед ономастичних студій найбільш продуктивними в Україні є антропонімічні, поетонімічні та топонімічні дослідження, в яких аналізуються відповідно власні особові назви, пропріативи, які побутують у художньому мовленні, та власні географічні найменування. У складі останніх розмежовуються, насамперед, характеристики гідронімів, ойконімів та мікротопонімів. Мікротопонімічні студії в основному виконані на матеріалі, зібраному в Західній Україні (це, зокрема, Буковина, Волинь, Галичина, Закарпаття, Поділля), при цьому слід зазначити, що комплексний аналіз власних назв дрібних географрічних об’ектів Північної Хмельниччини відсутній. Водночас характеристика вказаних пропріальних одиниць будуеться за зразком вивчення мікротопонімів, засвідчених в інших регіонах України, Крім того, отримані результати варто порівнювати з особливостями власних назв дрібних географічних об'єктів, засвідчених насамперед на суміжних територіях. Зрештою, необхідна констатація джерельної бази дослідження, зокрема переліків, реєстрів, словників і подібних видань, звідки можна отримати інформацію насамперед про колишні найменування денотатів, чимало з яких в усномовній практиці мешканців регіону вже не засвідчено. Усі власні назви ономасти кваліфікують як онімний простір, дефініщії якого практично однотипні в різних мовах протягом досить тривалого часу. У статті охарактеризовано історію вивчення власних назв дрібних географічних об’єктів як України, так і північних районів Хмельницької області. Було проаналізовано власні географічні назви у працях В.В. Лободи, Т.І. Поляруш, Л.П. Стичишиної, безпосередньо мікротопонімів (дисертації В.Ф. Баньоі, Н.І. Бицко, Л.П. Білінської, О.Б. Василик, Н.В. Вебер, О.Б. Галай, О.В. Заінчковської, Л.Б. Костик, О.Б. Лужецької, О.І. Михальчук, Н.М. Павликівської, О.І. Проць, Н.В. Сокіл, Н.Р. Яніцької) та місцевих географічних термінів (роботи Т.В. Громко і О.К. Данилюк). З'ясовано становлення термінологічної системи мікротопоніміки (студії Д.Г. Бучка і Н.В. Ткачової, В.В. Німчука, Н.В. Подольської, М.М. Торчинського). Визначено джерела для фріксації найменувань вказаного регіону (праці С.Д. Бабишина, Я.О. Пури, Н.М. Торчинської і М.М. Торчинського). Вибір теми нашого дослідження зумовило те, що мікротопонімія Північної Хмельниччини ще не була об’ектом окремого дослідження.

Ключові слова: власна назва дрібного географічного об'єкта, мікротопонім, мікротопоніміка, мікротопоніміст, мікротопонімія, історія вивчення найменувань.

Droblem statement. Among the onomastic studies, the most productive in Ukraine are anthroponymic, poetonymic and toponymic studies, which analyze proper names, propriatives that exist in artistic speech and have characteristics of hydronyms, oikonyms, and microtoponyms.

Recent research and publications. Microtoponymic studies are mainly based on the material collected in Western Ukraine (in particular: Bukovyna, Volyn, Halychyna, Transcarpathia, Podillya).
At the same time, the characterization of these proprial units is based on the model of studying microtoponyms, certified in other regions of Ukraine.

In addition, the obtained results should be compared with the peculiarities of proper names of small geographic objects, primarily certified in adjacent territories. Finally, it is necessary to state the source of the research base, including lists, registers, dictionaries and similar editions, from which it is possible to obtain information, first of all, on 
the former denotation names, many of which are not already certified in the initial practice of the inhabitants of that region.

Thus, the purpose of our article is to describe the bibliographic bases of the microtoponymy study of Northern Khmelnytsky region. Microtoponymic studies are important among other onomastic studies; they are represented in dissertations, monographs, dictionaries, articles and other publications. The West Ukraine toponyms are better covered (Bukovyna, Transcarpathia, Lviv, Podillya, Prykarpattya, Ternopil) than the microtoponymy of Northern Khmelnytskyi, the latter has not yet been the subject of a separate research, which has led to the choice of the topic of our paper.

Presentation of the main material. It should be noted that one of the first to study the names of small geographical objects (usually in combination with oykonyms, hydronyms and other varieties of proper names) was M. Kordub in the work "What Names of Settlements Tell Us" (Lviv, 1938), later in his dissertation research V.V. Loboda analyzed the Northern Black Sea toponymy: "Northern Black Sea Toponymy General and Regional Problems of the Ukrainian Toponymic System" (Kyiv, 1979), T.I. Poliarush in 1971 conducted "Comparative Study of the Word Formation of Hydronymia, Microtoponymy and Oikonymy (based on the Toponymy of the North-East Left Bank of Ukraine) and L.P. Stychyshyn researched "Problems of adjacent toponymy (on the material of the interdistribution of Kodyma and Savranka and adjacent territories" (Kyiv, 1976).

Much attention was devoted by scholars to the characterization of the actual microtoponyms (all or individual varieties) of certain regions. This is, in particular, the study of V.F. Banyoi (Uzh river basin), N.I. Bytsko (upper-middle Dniester), L.P. Bilinskaya (Pokutia), O.B.Vasylik (Uman region), N.V. Weber (Ivano-Frankivsk region), A.B. Galay (Transcarpathia), O.V. Zainchkovskaya (southeastern Podillya). Kh.I. Zikan (Uzhgorod), R.O. Lyashenko (Kropyvnytskyi), O.I. Mikhalchuk (Podgorye), N.M. Pavlikovskaya (Vinnytsia), V.E. Polyakova (Simferopol), O.I. Prots (north of Lviv region), N.V. Sokil (Skolivschina), I.G. Chekhovsky (Chernivtsi region), N.R. Yanytska (central and eastern Lviv regions). Of course, these studies are relevant to us in their methodology, methods of describing the microtoponym material, as well as the ability to compare the results with data related to other regions of Ukraine (especially adjacent territories).

Thus, N.I. Lisnyak, having surveyed 335 settlements of West Podillya (Ternopil), found more than 6000 geographical objects. The onyms (anthroponyms, macrotoponyms, oykonyms, microtoponyms, and hydronyms) served as the base of their names. The structural features distinguish two groups of names: simple (monosyllabic) and compound microtoponyms. The most productive way of word formation of microtoponymy is the lexical-semantic, and among the morphological the suffixal one.

A characteristic feature of the micro-toponymy of the Western Podillya is the transfer of the names of one object to another, adjacent to it [4]. O.V. Zainchkovska described more than 3000 names of microobjects of southeastern Podillya (based on the material of Kirovograd region) and found that the basic terminology of such names is predominant geographical terminology [2]. N.M. Pavlykivska performed lexico-semantic and word-forming analysis of about 3,000 names of stagnant reservoirs (lakes, swamps, ponds, wells, digs, peatlands, etc.) of Vinnytsia and partly those of Khmelnitsky regions [see: 5].

A systematic study of the 1,500 stagnant water names recorded by L.B. Kostyk in towns and villages of the Chernivtsi region and in individual villages of the Suceava district of Romania, made it possible to clearly establish the quantitative correlation between the appellative and onym derivatives. Hydronyms originating from the appellate bases make up $71 \%$ of the total denomination and $29 \%$ of the onym basics. It is characteristic that the names of ponds originate mainly from oikonyms, and anthroponyms serve as the sources of new names of wells and digs. In most cases, the names of lakes and swamps derive from geographical nomenclature words or lexemes that indicate the features of hydroobjects.

Geographical terminology is the most productive layer of the basic vocabulary for generating names of water objects. Appellative vocabulary in the hydronymy of the region is predominantly slavic in origin, but there are borrowed terms, primarily from Turkish, Romanian, German and Latin. The word formation of Bukovynian hydronyms is according to the models and methods characteristic of other regions of Ukraine. Among them, within the lexical-semantic mode of creation, the most productive are the hydronyms formed as a result of the animation of geographical terms (34\%); within the morphological range, the possessive formations dominate $(24 \%)$, less numerous are hydronyms (21\%) based on lexicalizing and animating word combinations [3].

An attempt to analyze the upper-middle Dniester hydronyms within the complex approach was made in the work by N.I. Bytsko, who analyzed interlanguage and inter-dialect connections and their reflections in hydronymics. Further development was provided for the interaction between microhydronomy and corresponding oikonymy. The analysis of primary and secondary origin of microhydronym is reduced to etymologization of not only the onyms themselves, but also their etymons (oykonyms, anthroponyms, appellatives) [1].

A.B. Vasilik's research is devoted to the analysis of more than 700 phonetic, grammatical, lexical, graphic-spelling variant names of the micro-objects of the Uman region, fixed in cartographic and written sources of the 17-19th centuries. It was determined that the appellative and onym vocabulary was the basis for the creation of microtoponyms.

The appellative names (51.2\%) are divided into two subgroups: naturogenic and anthropogenic in origin. The first subgroup includes microtoponyms that reflect the animal and plant life of the region, indicate the natural features of the area and contain the physical and geographical characteristics of the objects (size, shape, structure and properties of the soil, terrain, etc.). The source of names nomination of the second subgroup is the economic and practical activity of people.

Some microtoponyms indicate the tendency to create colonies, farms, and villages (related to the settlement policy of the Commonwealth and later 
that of the Russian Empire). The performance of lexico-semantic groups varied within different time periods. The microtoponyms, which designate flora and videoorthony, were most characteristic for the XVIIIth century. The advantage of a simple (one-lexem) form of expression is revealed.

Conclusions. Microtoponymic studies are prominent among other onomastic studies; they are represented in dissertations, monographs, dictionaries, articles, and other publications. The Western Ukrainian parts are better covered (Bukovyna, Transcarpathia, Lviv, Podillya, Prykarpattya, Ternopil), but the microtoponymy of Northern Khmelnytskyi has not yet been the subject of a separate study, which has led to the choice of the topic of our paper. Local geographic nomenclature has a particular bearing on microtoponymy (often it is even difficult to distinguish whether a lexeme is a proper geographical name or a dialect term); in addition, local geographical terminology actively motivates microtoponyms. Both theoretical and applied aspects of the analysis of proper names of small geographical objests are analyzed in numerous articles and abstracts.

We emphasize the importance of our work, first of all, for those works that were used as sources of illustrative material; this is "Oykonymy of northern Khmelnytsky region" by N.M. Gereta, "Dictionary of proper geographical names of Khmelnytsky region" and "Toponymy at School: on the materials of Khmelnytsky region".

\section{References:}

1. Bytsko N.I. Mikrohidronimiia Ternopilshchyny (Nazvy Neprotichnykh Vod): avtoref. dys. ... kand. filol. nauk: 10.02. 01 - ukr. mova / N.I. Bytsko. - Chernivtsi, 2012. - 20 s.

2. Zainchkovska O.V. Mikrotoponimiia Pivdenno-Skhidnoho Podillia (Na Materiali Kirovohradskoi Oblasti): avtoref. dys. ... kand. filol. nauk: 10.02.01 - ukr. mova / O.V. Zainchkovs`ka. - Kirovograd, 2009. - 20 s.

3. Kostyk L.B. Gidronimiya Bukovyny (nazvy neprotichnyh vod): avtoref. dys. ... kand. filol. nauk: 10.02.01 - ukr. mova / L.B. Kostyk. - Ivano-Frankivsk, 2003. - 20 s.

4. Lisnyak N.I. Mikrotoponimiya Zahidnogo Podillya: avtoref. dys. ... kand. filol. nauk: 10.02 .01 - ukr. mova / N.I. Lisnyak. - Uzhgorod, 2004. - 20 s.

5. Pavlykovskaya N.M. Leksyko-semantycheskye y slovoobrazovatel. nazvanyj neprotochnih vodohranylyshch Podolya: avtoref. dys. ... kand. fylol. nauk: 10.02.02 - ukr. mova / N.M. Pavlykovskaya. - Dnepropetrovsk, 1991. - 16 s.

\section{Список літератури:}

1. Бицко Н.І. Мікрогідронімія Тернопільщини (назви непротічних вод) : автореф. дис. ... канд. фрілол. наук : 10.02.01 - укр. мова / Н.І. Бицко. - Чернівці, 2012. - 20 с.

2. Заінчковська О.В. Мікротопонімія південно-східного Поділля (на матеріалі Кіровоградської області) : автоpedp. дис. ... канд. фрілол. наук : 10.02.01 - укр. мова / О.В. Заінчковська. - Кіровоград, 2009. - 20 с.

3. Костик Л.Б. Гідронімія Буковини (назви непротічних вод): авторефр. дис. ... канд. фрілол. наук : $10.02 .01-$ укр. мова / Л.Б. Костик. - Івано-Франківськ, 2003. - 20 с.

4. Лісняк Н.І. Мікротопонімія Західного Поділля : автореф. дис. ... канд. фрілол. наук : 10.02 .01 - укр. мова / Н.I. Лісняк. - Ужгород, 2004. - 20 с.

5. Павликовская Н.М. Лексико-семантические и словообразовательные типы названий непроточных водохранилищ Подолья : автореф. дис. ... канд. фрилол. наук : 10.02 .02 - укр. язык / Н.М. Павликовская. - Днепропетровск, 1991. - 16 с. 